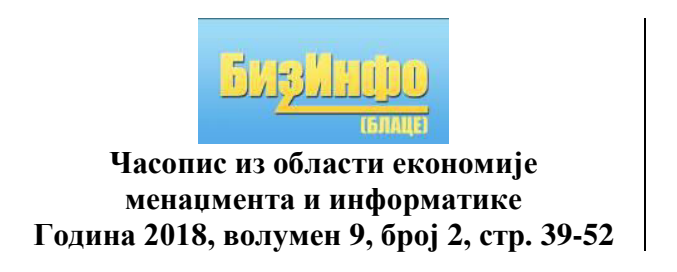

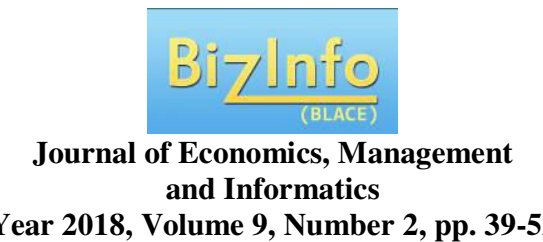

Year 2018, Volume 9, Number 2, pp. 39-52

\title{
ACHIEVED LEVEL OF TOURISM DEVELOPMENT IN THE REPUBLIC OF SERBIA
}

\section{ДОСТИГНУТИ НИВО РАЗВОЈА ТУРИЗМА У РЕПУБЛИЦИ СРБИЈИ}

\author{
Goran Perić ${ }^{1}$ \\ Business School of Applied Studies in Blace
}

Mira Avramović

Higher Business School of Professional Studies in Leskovac

Marija Stojiljković

Business School of Applied Studies in Blace

\begin{abstract}
It is known that the long-standing political and economic environment in our country has stopped the development of tourism and that the quality and diverse resource base of the Republic of Serbia is not sufficiently utilized. The offer of Serbian tourism products, spontaneously developed for the needs of domestic tourism, is not able to respond to the contemporary trends of the international tourist market, because there have been major changes in the market according to which the Republic of Serbia has not adapted its tourist offer. This has directed the subject of research in this paper to determine the achieved level of tourism development in the Republic of Serbia. Based on the new demands of modern tourists and global trends in tourism, the Republic of Serbia has the opportunity to capitalize its current position, to form a tourist offer and to achieve significant growth in the tourism sector and thereby provide a place on the world tourist map.
\end{abstract}

Keywords: tourism, Republic of Serbia, tourism traffic

\footnotetext{
${ }^{1}$ goran.peric@vpskp.edu.rs
} 
Резиме: Познато је да је дугогодишњи политички и економски амбијент у нашој земљи зауставио развој туризма и да квалитетна и разнолика ресурсна основа Републике Србије није довољно искоришћена. Понуда српских туристичких производа, која се спонтано развијала за потребе домаћег туризма, није у стаюу да одговори савременим трендовима међународног туристичког тржишта данас јер су се на том тржишту догодиле велике промене према којима Република Србија није прилагодила своју туристичку понуду. То је усмерило предмет истраживања у овом раду да утврдимо достигнути ниво развоја туризма у Републици Србији. На основу нових захтева савремених туриста и глобалних трендова у туризму, Република Србија ииа шансу да искористи своју тренутну позицију, обликује туристичку понуду и оствари значајан раст у туристичком сектору и самим тим обезбеди место на светској туристичкој мапи.

Кључне речи: туризам, Република Србија, туристички промет

\section{INTRODUCTION}

The modern development of tourism is, above all, based on the original quality of space and resources (Terzić \& and Bjeljac, 2015). It is known that the long-standing political and economic environment in our country has stopped the development of tourism and that the quality and diverse resource base of the Republic of Serbia is has not been sufficiently exploited. This imposes an obligation to for us to innovate the development of tourism through the process of innovation of the whole economy, taking care to ensure sustainable development, which implies rational use of space and resources.

The offer of Serbian tourist products today, spontaneously developed for the needs of domestic tourism, is not able to respond to the contemporary requirements of the international tourist market because major changes in the market occurred to which the Republic of Serbia did not adjust its tourist offer. In order for the Republic of Serbia to take its place in the international tourist market, it must significantly increase the competitiveness and attractiveness of tourism products based on the principles of sustainable development. Analyses of current and expected trends indicate that the future volume and structural changes in tourist demand will be reflected through the increased use of modern information technologies, communications and transports, by redirecting demand to destinations with original natural values and a high degree of ecological stability, a marked increase of interest in ecological values, restoring nature and expanding the knowledge horizon. It is estimated that travel for health and preventive care will be dominant in the 21 st century. 
In this paper, desk methods will be used for the review of literature and other studies, strategic documents in the field of tourism, as well as reports of relevant international organizations. Secondary statistical data from the Republic Statistical Office, the World Tourism Organization (UNWTO) and the World Travel and Tourism Council (WTTC) will be used for the analysis of tourism traffic and the impact of tourism on the economy of the Republic of Serbia.

\section{ACHIEVED LEVEL OF TOURISM DEVELOPMENT}

In the past, the Republic of Serbia faced a number of problems which among other things influenced the development of tourism. The intensive development of tourism in the Republic of Serbia began in 1965, when the number of domestic and foreign tourists exceeded 2.6 million, and the number of overnight stays exceeded 8 million. In the period from 1970 to 1985 , tourism as a business activity was a priority direction of the overall economic development of the Republic of Serbia. In this period, the Republic of Serbia had more influence on the creation of a tourist offerand, then, the achieved results in the entire economy were very notable (Gligorijević \& Gligorijević, 2012). Since 1985, there has been a decline in tourist traffic in the Republic of Serbia.

The last decade of the 20th century was a difficult period in the development of tourism in the Republic of Serbia, when tourism as a business activity shared the fate of total economic stagnation and recession in the country. The breakup of the SFRY, war events, economic sanctions, hyperinflation, NATO bombing of the Republic of Serbia, significantly influenced the decline of tourism in this period. A negative image of the Republic of Serbia was created. The circumstances in which the Republic of Serbia found itself during the 1990s influenced the negative development of tourism. Negative tendencies were expressed through (Gligorijević \& Petrović, 2008):

- reducing the number of tourists (domestic and foreign) and the number of their overnight stays,

- a drastic fall in foreign exchange income from tourism,

- lack of investment activities in tourism,

- reduction of the decline of this economic activity for economic development,

- Low level of utilization of accommodation capacities,

- Non-motivation of employees as a result of low wages.

The image of the Republic of Serbia in the world begins to be improved at the beginning of the 21 st century, through its return to numerous international organizations and institutions and major changes in the internal plan, and still it takes a lot of time and effort to take an adequate place in the international 
tourist market, according to the tourist potentials at its disposal, which will enable it to achieve constant and stable growth of foreign tourist traffic (Ubavić, 2016). The big changes that took place on the world tourist market have bypassed the Republic of Serbia, because Serbia did not adjust its tourist offer to world trends, and it is necessary to dramatically improve the competitiveness of the tourist offer according to the desired positioning in the tourist market (Rakić,et al, 2014).

The achieved level of tourism development in the Republic of Serbia, despite the existence of a quality and diversified resource base, significantly lags behind all the relevant indicators in relation to the resource and market possibilities of its development (Čerović, et al. 2015). In 2017, the Republic of Serbia generated arrivals of domestic and foreign tourists, as well as overnight stays, which is $65 \%$ of tourist turnover from 1985, that is, $60 \%$ of the number of overnight stays. According to the World Travel and Tourism Council (WTTC), the total contribution of tourism in 2017 was 294 billion, creating a 6.7\% of GDP (Travel \& Tourism Economic Impact 2018 Serbia). The fact that the number of employees is continuously decreasing, despite the increase in the number of registered businesses, especially in the housing and food sector, suggests that the black market is significantly present in this sector (Čerović et al. 2015).

\subsection{Tourist traffic in the Republic of Serbia}

According to all relevant indicators, the Republic of Serbia, as a tourist destination, takes a pretty poor position on the regional and international tourist market, and it does not match its tourist potential (Ubavić, 2016). This is confirmed by the fact that according to the Tourism and Traveling Competitiveness Index developed by the World Economic Forum, the Republic of Serbia is 95th in the world among the total of 136 countries surveyed (The Travel \& Tourism Competitiveness Report 2017).

When the tourist demand is measured, the most important indicators are the number of visitors, the number of nights and the amount of consumption. Each indicator will be specially observed and analyzed on the basis of statistical data.

The number of tourists who visited the Republic of Serbia in the period from 2000 to 2017 ranged from 1.889 .771 and 3.085.866 in 2017 when the largest number of tourists was realized, while in the same period the number of nights ranged between 6.407.255 and 8.325.144 million, which can be seen in the table below. 
Table 1. Total number of tourist arrivals and overnight stays in the Republic of Serbia (2000 - 2017)

\begin{tabular}{|l|c|c|c|c|c|c|}
\hline \multirow{2}{*}{ Year } & \multicolumn{3}{|c|}{ Arrivals of tourists } & \multicolumn{3}{c|}{ Overnight stays } \\
\cline { 2 - 7 } & Total & Domestic & Foreign & Total & Domestic & Foreign \\
\hline 2000. & 2.166 .354 & 2.001 .128 & 165.226 & 7.688 .134 & 7.257 .041 & 431.093 \\
\hline 2001. & 2.129 .128 & 1.886 .603 & 242.525 & 7.195 .272 & 6.602 .672 & 592.600 \\
\hline 2002. & 2.209 .675 & 1.897 .612 & 312.063 & 7.206 .734 & 6.468 .473 & 738.261 \\
\hline 2003. & 1.997 .947 & 1.658 .664 & 339.283 & 6.684 .592 & 5.892 .890 & 791.702 \\
\hline 2004. & 1.971 .683 & 1.579 .857 & 391.826 & 6.642 .623 & 5.791 .564 & 851.059 \\
\hline 2005. & 1.989 .367 & 1.536 .321 & 453.158 & 6.499 .241 & 5.507 .138 & 992.087 \\
\hline 2006. & 1.889 .771 & 1.420 .929 & 468.842 & 6.407 .225 & 5.391 .913 & 1.015 .312 \\
\hline 2007. & 2.306 .558 & 1.610 .513 & 696.045 & 7.328 .692 & 5.853 .017 & 1.475 .675 \\
\hline 2008. & 2.266 .166 & 1.619 .672 & 646.494 & 7.334 .106 & 5.935 .219 & 1.398 .887 \\
\hline 2009. & 2.018 .466 & 1.373 .444 & 645.022 & 6.761 .715 & 5.292 .613 & 1.469 .102 \\
\hline 2010. & 2.000 .597 & 1.317 .916 & 682.681 & 6.413 .515 & 4.961 .359 & 1.452 .156 \\
\hline 2011. & 2.068 .610 & 1.304 .443 & 764.167 & 6.644 .738 & 5.001 .684 & 1.643 .054 \\
\hline 2012. & 2.079 .643 & 1.269 .676 & 809.967 & 6.484 .702 & 4.688 .485 & 1.796 .217 \\
\hline 2013. & 2.192 .435 & 1.270 .667 & 921.768 & 6.567 .460 & 4.579 .067 & 1.988 .393 \\
\hline 2014. & 2.192 .268 & 1.163 .536 & 1.028 .732 & 6.086 .275 & 3.925 .221 & 2.161 .054 \\
\hline 2015. & 2.437 .165 & 1.304 .944 & 1.132 .221 & 6.651 .852 & 4.242 .172 & 2.409 .680 \\
\hline 2016. & 2.753 .951 & 1.472 .165 & 1.281 .426 & 7.533 .739 & 4.794 .741 & 2.738 .998 \\
\hline 2017. & 3.085 .866 & 1.588 .693 & 1.497 .173 & 8.325 .144 & 5.150 .017 & 3.175 .127 \\
\hline S0urc. Pe
\end{tabular}

Source: Републички завод за статистику Србије, 2005. Статистички годишњак Србије 2005; Čerović, S., Barjaktarović, D., Knežević, M. 2015. Podrška razvoju turizma kao faktor konkurentnosti Srbije kao turističke destinacije; Републички завод за статистику, 2018. Статистички годишњак Републике Србије 2018, adapted for the needs of the author

Based on Table, 1 it can be concluded that the total tourist turnover in the observed period showed growth and fall in certain years. Foreign tourist arrivals in this period increased year by year, except in 2008 and 2009, when there was a slight drop, having in mind the fact that in these years there was a decline in international tourism traffic due to the first wave of global financial crisis and economic recession. The percentage share of foreign tourists in the total number of arrivals in the observed period increased significantly from $7.63 \%$ in 2000 to $47.93 \%$ in 2017, which is an encouraging fact.

The situation is the same concerning the number of overnight stays when talking about the relation of domestic and foreign tourists. In the observed period, there was a constant increase in the number of overnight stays of foreign tourists in the total number of overnight stays. Only in 2008, there was a decrease of $5.2 \%$ in coparison to 2007 , as well as 2010 , when the decrease was only $1.16 \%$. The share of foreign overnight stays in percentage ranges from $5.94 \%$ to $38.14 \%$ in 2017.

The effects of tourism are reflected in its impact on the balance of payments. The movement of foreign exchange inflows and outflows from tourism in the Republic of Serbia is presented in Table 2. for the period from 2007, when 
there was a change in the methodology in calculating the consumption of foreign tourists, to 2017.

Table 2. Foreign exchange inflow and outflow from tourism in the Republic of Serbia (2007 - 2017)

\begin{tabular}{|c|c|c|c|}
\hline Year & $\begin{array}{c}\text { Foreign exchange inflows } \\
\text { from tourism in millions of } \\
\text { USD }\end{array}$ & $\begin{array}{c}\text { Foreign exchange outflows } \\
\text { from tourism in millions of } \\
\text { USD }\end{array}$ & Balance \\
\hline 2007. & 617 & 1.041 & -424 \\
\hline 2008. & 944 & 1.254 & -310 \\
\hline 2009. & 865 & 959 & -94 \\
\hline 2010. & 798 & 953 & -155 \\
\hline 2011. & 992 & 1.114 & -122 \\
\hline 2012. & 906 & 1.350 & -444 \\
\hline 2013. & 1.053 & 1.117 & -64 \\
\hline 2014. & 1.139 & 1.177 & -38 \\
\hline 2015. & 1.068 & 1.097 & -29 \\
\hline 2016. & 1.151 & 1.202 & -51 \\
\hline 2017. & 1.180 & 1.215 & -70 \\
\hline
\end{tabular}

Source: Стратегија развоја туризма Републике Србије за период 2016. - 2025;

Министарство трговине, туризма и телекомуникације, Корисне информације туристички промет Србија, adapted for the needs of the author

The table above shows the positive trend of foreign exchange inflows for the observed period, which resulted in a clear increase in the number of tourists from the countries of the region and European markets. On the other hand, the residents of the Republic of Serbia allocate significant funds for travelling abroad and, thus, influence the negative balance in the balance of payments, that is, for the observed period, a higher foreign exchange outflow was achieved in all years.

In the period from 2007 to 2012, the foreign exchange inflow from tourism ranged from 617 to 992 million USD, with oscillations for individual years. Over the past four years, the growth of foreign exchange inflows from tourism has been noticed.

The observed period is characterized by constant growth of foreign exchange outflow from tourism. When we look at revenues and expenditures from tourism, we see a permanent deficit. The largest deficit was recorded in 2012 of 444 million USD, then in 2007 and 2008. In the same year, foreign currency outflows increased by $20.46 \%$ compared to 2007, so in 2009 and 2010 there was be a fall compared to the 2007 deficit. Since 2013, there has been a noticeable decline in foreign exchange outflows, which makes 2015 the year with the least deficit of 29 million USD. This positive change in the reduction of travel expenses for citizens of the Republic of Serbia abroad was also contributed by the action of the Government of the Republic of Serbia 
and the line ministry in the form of tourist vouchers aimed at stimulating the development of domestic tourism.

In order for the Republic of Serbia to increase revenues from foreign tourists in the future and to achieve a balanced balance of payments, it is necessary to adapt the existing tourist offer to every market segment. On the other hand, it is necessary to systematically work on creating the necessary conditions for as few as possible citizens of the Republic of Serbia traveling abroad to meet their tourist needs.

\subsection{Material Tourism Base of the Republic of Serbia}

The material base is a very important factor in the direct consumption of tourism. The material base of tourism consists of accommodation capacities and transport infrastructure, which will be discussed below. The realization of tourist traffic and the effects of tourism depend on the harmonization of the material base with natural and created tourist resources.

\subsubsection{Accommodation facilities}

At the end of $2004,85,867$ thousand tourist beds were registered in the Republic of Serbia, distributed in 695 business facilities, which had a total of 36,163 accommodation units (Strategija razvoja turizma: prvi fazni izveštaj, 2005). According to the data of theStatistical Office of the Republic of Serbia in 2017, the Republic of Serbia has 106,029 thousand beds, or $23.48 \%$ more than in 2004, as well as with 44,813 accommodation units, which is $23.92 \%$ more than the number in 2004 ..

According to the data of the Ministry of Trade, Tourism and Telecommunications in October 2017, the number of categorized facilities for tourist accommodation amounts to 358 , while the number of accommodation units reached a figure of 16,962 and the number of beds is 31,791 . These data by type of objects are shown in Table 3.

Table 3. Categorized facilities for tourist accommodation in the Republic of

Serbia

\begin{tabular}{|c|c|c|c|}
\hline $\begin{array}{c}\text { Types of categorized facilities for } \\
\text { tourist accommodation }\end{array}$ & $\begin{array}{c}\text { Number of } \\
\text { facilities } \\
\text { units }\end{array}$ & $\begin{array}{c}\text { Number of } \\
\text { accommodation }\end{array}$ & $\begin{array}{c}\text { Number of } \\
\text { beds }\end{array}$ \\
\hline Hotels & 342 & 16.431 & 30.724 \\
\hline Motels & 8 & 200 & 361 \\
\hline Pensions & 3 & 97 & 176 \\
\hline Tourist / Holiday resorts & 5 & 234 & 531 \\
\hline TOTAL & 358 & 16.962 & 31.791 \\
\hline
\end{tabular}


Source: Министарство трговине, туризма и телекомуникације, Корисне информације туристички промет Србија - категоризација: http://mtt.gov.rs/sektori/sektor-za-

turizam/korisne-informacije-turisticki-promet-srbija-kategorizacija/, adapted for the needs of the author

If we add the number from the previous table to the number of uncategorized accommodation units and the number of beds, we get information that around $70 \%$ of the accommodation capacities in the Republic of Serbia are not categorized. In the total number of accommodation facilities, hotels have the largest share, both by number of accommodation units (41.5\%) and by number of beds $(36.5 \%)$.

The structure of hotel capacities has changed in the last few years when new hotels were built, primarily with $4 *$, famous brands (Radisson Blu, Crowne Plaza, Luxury Collection - Starwood, Falkeinsteiner, Holiday Inn, Best Western) and above all, Belgrade, Subotica, Novi Sad and Niš, as well as the construction and adaptation of a number of domestic hotels (Čerović, et al., 2015). Concerning hotel capacities, out of a total of 36,088 hotel beds in 2004 , the largest share, as much as $65 \%$, was spent on hotel capacities of category $2 *$ and $3 *$. Hotels with $4 *$ and $5 *$ represent about $11 \%$ of the total hotel capacity in Serbia, while hotels with $1 *$ and unclassified facilities account for as much as $24 \%$ of the total hotel accommodation registered in the country (Strategija razvoja turizma: prvi fazni izveštaj, 2005). The situation in 2017 is considerably more favorable, so hotels with $3 *(38.1 \%)$, $4 *(34.21 \%)$, followed by $2 *(20.47 \%)$, with $1 *(4.68 \%)$ and hotels with 5 * $(2.63 \%)$ (Ministry of Trade, Tourism and Telecommunications).

According to the data of the Ministry of Trade, Tourism and Telecommunications in the territory of the city of Belgrade, there are 94 categorized hotels, which is $27.48 \%$ of the total hotel capacity in the Republic of Serbia. Novi Sad and Nis have 23 or 22 categorized hotels, while in Kragujevac there are 17 hotels of different categories. It can be concluded that these four city centers have $45.61 \%$ of the total hotel capacity. Other categorized hotel facilities are located in mountain and spa destinations, as well as in smaller tourist resorts.

\subsubsection{Traffic infrastructure}

A good traffic connection of tourist destinations with places of tourist demand is one of the most important factors for the development of tourism. The significance and role of transport in the development of tourism is reflected in the size and condition of the transport infrastructure. Transport infrastructure in the Republic of Serbia can be assessed as insufficiently developed, although in the last three years, significantly improved works, primarily on road transport infrastructure, at the end of Corridor 10. 
We can conclude that the Republic of Serbia had a highway in the length of $374 \mathrm{~km}$ in 2004 (Strategija razvoja turizma: prvi fazni izveštaj, 2005). In recent years, works have been intensified at the completion of Corridor 10, as well as on the construction of Corridor 11, and according to the Roads of Serbia in 2017, the Republic of Serbia built $781 \mathrm{~km}$ of highway.

The Republic of Serbia has at least 19 airports with asphalted runways and another 44 airports with unpaved runways (Strategija razvoja turizma: prvi fazni izveštaj, 2005). At present, only two airports for civil transport operate in the Republic of Serbia, in Belgrade and Nis. The airport "Nikola Tesla" in Belgrade in 2017 received 5,343,420 passengers and, after the airport in Sofia, it is the busiest airport in the region (Airport Nikola Tesla Belgrade, 2018). The situation is drastically worse at the Constantine the Great airport in Niš, which has existed for almost 31 years and which in 2017 had a turnover of only 331,582 passengers (Nis Constantine the Great Airport, 2018). In the last few years there has been an increase in the number of lowcost companies that have regular flights from this airport. The biggest advantage of this airport are cheaper tickets and low airport taxes.

Another airport in the Republic of Serbia is ready to receive the first passenger aircraft. This is the former military airport Lađevci near Kraljevo, which has been turned into the civil airliner "Morava" and since 2012 it has been waiting to receive the first passengers.

Railway traffic in the Republic of Serbia is characterized by poor conditions of infrastructure and transport capacities. The railway network in the Republic of Serbia is 3,739 km of railway, of which 3,444 are single-track and $295 \mathrm{~km}$ double-track lines (Odluka Narodne skupštine RS, 2017). Only one third of the mentioned lengths of railway network is electrified, while in EU countries the percentage of electrification of the railway is over $50 \%$. Due to the poor state of the railway infrastructure, the average speed on our railways is only $27.9 \mathrm{~km}$ per hour, while the minimum permissible speeds in Europe are $50 \mathrm{~km}$ per hour (Drobnjak, 2012).

In addition to the accessibility by road, rail and air, river traffic is extremely important for the Republic of Serbia, with the Danube's navigability as the largest economic potential (Strategija razvoja turizma: prvi fazni izveštaj, 2005) with its $587 \mathrm{~km}$. Nevertheless, river passenger transport, which forms the basis for nautical tourism in the Republic of Serbia, is underdeveloped. According to the Port Authority's analysis, passenger river traffic shows a steady increase in cruising. In 2017, 994 passenger boats were registered, with 131,646 passengers, which is, compared with 2016, the number of 
landings increased by $5 \%$ and the number of passengers by $10 \%$ (Godišnji bilten, 2017).

\section{KEY TOURIST PRODUCTS OF THE REPUBLIC OF SERBIA}

The key tourist products of the Republic of Serbia are the spa resorts, mountain resorts and large city centers where over $70 \%$ of tourist traffic is realized, and $80 \%$ of overnight stays. Table 4 shows the participation of the key tourist products in 2016.

Table 4. Participation of the key tourist products in the total tourist traffic of the Republic of Serbia in 2016

\begin{tabular}{|l|c|c|c|c|c|c|}
\hline & \multicolumn{3}{|c|}{ Tourist arrivals } & \multicolumn{3}{c|}{ Tourist overnight stays } \\
\cline { 2 - 7 } & Total & Domestic & Foreign & Total & Domestic & Foreign \\
\hline $\begin{array}{l}\text { Republic of } \\
\text { Serbia }\end{array}$ & $\mathbf{2 . 7 5 3 . 5 9 1}$ & $\mathbf{1 . 4 7 2 . 1 6 5}$ & $\mathbf{1 . 2 8 1 . 4 2 6}$ & $\mathbf{7 . 5 3 3 . 7 3 9}$ & $\mathbf{4 . 7 9 4 . 7 4 1}$ & $\mathbf{2 . 7 3 8 . 9 9 8}$ \\
\hline $\begin{array}{l}\text { Large } \\
\text { centres }\end{array}$ & 1.035 .571 & 223.170 & 812.401 & 2.034 .187 & 388.221 & 1.671 .972 \\
\hline Spas resorts & 477.102 & 391.085 & 86.017 & 2.085 .044 & 1.831 .205 & 253.839 \\
\hline $\begin{array}{l}\text { Mountains } \\
\text { resorts }\end{array}$ & 522.424 & 425.793 & 96.631 & 1.928 .533 & 1.641 .427 & 287.106 \\
\hline Shares tourists & $73,91 \%$ & $70,65 \%$ & $77,65 \%$ & $80,27 \%$ & $80,47 \%$ & $80,79 \%$ \\
\hline $\begin{array}{l}\text { Other } \\
\text { resorts }\end{array}$ & 605.136 & 369.032 & 236.104 & 1.216 .312 & 763.017 & 453.295 \\
\hline Other resorts & 113.358 & 63.085 & 50.273 & 269.663 & 170.871 & 98.792 \\
\hline
\end{tabular}

Source: Perić, G., Gašić, M., Stojiljković, M., Ivanović, V. 2017. Perspectives of

Development of Spa Tourism in Serbia. Journal of Awareness, 2:Special Issue, pp. 597-614, adapted for the needs of the author

The Republic of Serbia has many thermomineral sources that are not properly valued and used in tourism. With over 50 spa and climatic sites and over 1000 sources, of which about 500 sources of cold and warm mineral water, as well as the richness of natural mineral gases and medicinal mud, there is a huge potential for health / wellness tourism (Strategija razvoja turizma RS, 2016). That is why The Republic of Serbia is called the "state of spas". In recent years, a lot has been done in modernizing this tourist product, and besides, this product is still oriented towards domestic demand, bearing in mind that the spas of the Republic of Serbia has about 20\% foreign tourists. In the past decade, wellness and health tourism and recreational tourism within the tourism industry have become one of the fastest growing segments and a very profitable market niche (Perić, et al., 2018).

Thanks to their natural-ecological properties, landscape qualities, biodiversity, developmental potentials and other characteristics, the mountainous areas of the Republic of Serbia represent a valuable natural resource (Krunić et al., 2010), which is not significantly valorised. The most 
visited mountain centers are Kopaonik, Zlatibor, Tara and Divcibare, which account for more than $70 \%$ of the structure of tourist traffic realized in mountain centers. As with spa tourism, domestic tourists are predominant in overall tourism, while the low percentage of foreign tourists, which is the result of the inadequate tourist offer, as well as the lack of marketing activities.

In recent years, a tendency of increased interest of tourists for large city centers has been noticed. Belgrade is the leading tourist product of the Republic of Serbia, and Belgrade and Novi Sad are the only recognizable city tourist destinations on the international tourist market (Štetić et al., 2014). These two cities together absorb $37.61 \%$ of the total tourism turnover of the Republic of Serbia, or $63.4 \%$ of foreign tourists. Belgrade and Novi Sad have a dominant position when it comes to foreign tourists. In the structure of tourists who are coming to these two city centers, over $70 \%$ are foreign tourists, who achieve over $80 \%$ of overnight stays. The number of domestic tourists in these two cities still largely depends on official travels.

Lately, rural tourism is gradually developing in the Republic of Serbia, and in line with contemporary trends that are characterized by an increasing focus on rural tourism destinations. According to the current categorization of tourist sites in the Republic of Serbia, there are no special places for rural tourism. Tourist traffic in other tourist destinations and other places listed in the categorization of tourist destinations can be considered as touristic places where tourism transport is realized in rural tourism (Gašić et al., 2015). Accordingly, rural tourism in the Republic of Serbia participates with $26 \%$ in the total tourist traffic.

One of the most characteristic tourist products of the Republic of Serbia are manifestations that have emerged as a product of traditional Serbian adherence to festivals (Strategija razvoja turizma: prvi fazni izveštaj, 2005). According to some estimates, the Republic of Serbia has between 2000 and 3000 events annually, and the greatest attention of domestic and foreign tourists attracts events that are dedicated to cultivating tradition, folk customs, folklore and crafts. The most famous and most visited manifestations are the Trumpet Festival in Guca, Exit in Novi Sad, Beer Fest in Belgrade and others.

\section{CONCLUSION}

The achieved level of tourism development in the Republic of Serbia, despite the existence of a quality and diversified resource base, is significantly lagging in relation to the resource and market possibilities of its development (Črović et al., 2015). We can conclude that tourism transport in our country 
is far behind its main competitors, which is a consequence of neglecting and not recognizing tourism as one of the priority economic branches. In the previous period, the Republic of Serbia has not conducted an active tourism policy, and it missed the chance to make a significant competitive advance in the international tourist market. Nevertheless, in the last several years, the total tourism turnover has been steadily growing, with mostly domestic tourists with more than $50 \%$ participation. Positive tendency is certainly the growth of foreign tourist arrivals. The Republic of Serbia cannot boast even with the existing material base. Only the fact that at the end of this year or the beginning of the next year, the road corridor 10 is finally encouraged. In the previous period, there were no investments in activating smaller airports in the areas farther from the capital city, which would create conditions for the arrival of low-cost airlines. The structure of accommodation capacities has been changed in the last few years, primarily in qualitative terms, and because of the arrival of well-known hotel chains. However, accommodation capacities meeting international standards are limited to Belgrade and Novi Sad and the leading tourist destinations in the country. In the previous period, the largest number of domestic and foreign tourists visited major city centers, namely Belgrade and Novi Sad, followed by spa and mountain destinations and rural areas. A large number of tourists were also directed to visit numerous events dedicated to cultivating tradition and folk customs.

Today, it can be said, for the Republic of Serbia, that it has only comparative advantages in tourism, because it has a diverse structure of tourist offer, it is located near new and traditional tourist markets, has a long history and general recognition, preserved natural resources and anthropogenic resources, relatively good communication and great human potential (Ubavić, 2015).

Considering the state of the material base for the development of tourism in the coming period, it is necessary to improve the development of traffic, tourist, communal and other infrastructure. Since the Republic of Serbia has limited resources for investments, it is necessary to create a favorable environment for domestic and foreign investors, as well as to "free" all resourcers that create costs, but do not create added value. Solving property legal relations in the spas, accelerated by the privatization of state-owned hotel facilities, would release significant assets that would engage in the development of tourism. We should not neglect the funds from EU funds and other international institutions.

\section{REFERENCE}

1. Gašić, M., Perić, G., Ivanović, V., 2015. Razvijenost ruralnog turizma u Republici Srbiji. BizInfo (Blace), 6(2), str. 71-81. 
2. Gligorijević, Ž., Gligorijević, A., 2012. Turizam - karakteristike i perspektive razvoja. SVEN, Niš.

3. Gligorijević, Ž., Petrović, J., 2008. Turizam u funkciji strukturnog prilagođavanja privrede Srbije. Ekonomika, 53(1-2), str. 20-26.

4. Krunić, N., Milijić, S., Đurđević, J. 2010. Razvoj planinskog turizma u Srbiji i zemljama u okruženju. Arhitektura i urbanizam, (29), str. 39.

5. Ministarstvo trgovine turizma i usluga, 2005. Strategija razvoja turizma: prvi fazni izveštaj, Beograd: Horwath Consulting Zagreb i Ekonomski fakultet Beograd.

6. Народна Скупштина Републике Србије, 2017. Одлука о Националном програму јавне железничке инфраструктуре за период од 2017. до 2021. године. Београд: Народна Скупштина Републике Србије.

7. Perić, G., Gašić, M., Stojiljković, M., Ivanović, V., 2017. Perspectives of Development of Spa Tourism in Serbia. Journal of Awareness, 2:Special Issue, pp. 597-614.

8. Perić, G., Gašić, M., Stojiljković, M. and Nešić, I., 2018. The impact of employee satisfaction on the tourist satisfaction with the services ofspa tourism. Economics of Agriculture, 65(2), pp. 617-632.

9. Ракић, С., Мухи, Б., Томка, Д., 2014. Утицај светске економске кризе на глобални туристички промет са посебним освртом на Републику Србију. Пословна економија, 8(1), стр. 281-306.

10. Републички завод за статистику Србије, 2005. Статистички годиињак Србије 2005. Београд: Републички завод за статистику Србије.

11. Републички завод за статистику, 2018. Статистички годишњак Републике Србије 2017. Београд: Републички завод за статистику.

12. Terzić, A., Bjeljac, Ž., 2015. Problemi revitalizacije argitektonskog nasleđa i turističkog uređenja u Srbiji. Kultura polisa. 28, str. 478488.

13. Ubavić, P., 2016. Pozicioniranje Srbije kao turističke destinacije na međunarodnom turističkom tržištu. Megatrend Review, 13(2), str. 97118.

14. Ubavić, P., 2015. Turistička politika i mogući pravci razvoja turizma u Srbiji. Ekonomija: teorija i praksa, 8(1), str. 16-31.

15. Влада Републике Србије, 2016. Стратегија развоја туризма Републике Србије за период 2016. - 2025. Београд: Влада Републике Србије.

16. Čerović, S., Barjaktarović, D., Knežević, M., 2015. Podrška razvoju turizma kao faktor konkurentnosti Srbije kao turističke destinacije. U: Zbornik radova, Singidunum Univerzitet, SITCON 2015 Međunarodna naučna konferencija Univerziteta Singidunum: 
Konkurentnost turističke destinacije, Beograd, 25. septembar 2015. Beograd: Singidunum Univerzitet.

17. Štetić, S., Cvijanović, D., Šimičević, D., 2014. Posebni oblici turizma Dunavskog regiona Srbije. Monografija, Beograd: Institut za ekonomiku poljoprivrede.

18. Airport Nikola Tesla Belgrade, 2018. Traffic Figures. [online] Airport Nikola Tesla Belgrade. Available at: <http://www.beg.aero/en/strana/11161/traffic-figures> [Accessed 2 December 2018.].

19. Агенција за управљање лукама, 2017. Годишњи билтен - Број 102. [pdf] Available at: <https://www.aul.gov.rs/folder/godisnjibilten-2017.pdf> [Accessed 4 December 2018.].

20. Drobnjak, J., 2012. Saobraćaj Srbije. [online] Beograd: Markoekonomija.org. Available at: <https://www.makroekonomija.org/0-raniji-autori-i-citati/z-jovodrobnjak/saobracaj-srbije> [Accessed 4 December 2018.].

21. Министарство трговине, туризма и телекомуникација, 2017. Корисне информачије - туристички промет Србија категоризација. [online] Министарство трговине, туризма и телекомуникација Available at: <http://mtt.gov.rs/sektori/sektor-zaturizam/korisne-informacije-turisticki-promet-srbija-kategorizacija/> [Accessed 2 December 2018.].

22. Nis Constantine the Great Airport, 2018. Statistics. [online] Niš: Nis Constantine the Great Airport. Available at: <http://nisairport.com/en/traffic-figures/> [Accessed 2 December 2018.].

23. Word Travel \& Tourism Council (WTTC), 2018. Travel \& Tourism Economic Impact 2018 Serbia. [pdf] London: WTTC. Available at: <https://www.wttc.org/-/media/files/reports/economic-impactresearch/countries-2018/serbia2018.pdf> [Accessed 2 December 2018.].

24. World Economic Forum, 2017. The Travel \& Tourism Competitiveness Report 2017. [pdf] Geneva: World Economic Forum. Available at: <http://www3.weforum.org/docs/WEF_TTCR_2017_web_0401.pdf> [Accessed 19 November 2018.].

Received: 13 December, 2018

Accepted: 23 December, 2018 